\title{
Syndactyly type 6
}

INSERM

\section{Source}

INSERM. (1999). Orphanet: an online rare disease and orphan drug data base. Syndactyly type 6. ORPHA:295012

Syndactyly type 6 is a rare, genetic, non-syndromic, congenital limb malformation disorder characterized by unilateral fusion of second to fifth fingers, amalg amation of distal phalanges in a knot-like structure, and second- and third-toe fusion. Some individuals present only with webbing between second and third toes, without involvement of fingers. 